OPEN ACCESS

Edited by:

Xiaogang $W u$,

Institute for Systems Biology,

United States

Reviewed by:

Dougu Nam

Ulsan National Institute of Science and

Technology, South Korea

Peng Tan,

Houston Methodist Research Institute,

United States

${ }^{*}$ Correspondence:

Dezhi Mu

mudz@scu.edu.cn

tThese authors have contributed equally to this work.

Specialty section:

This article was submitted to Systems Biology,

a section of the journal

Frontiers in Physiology

Received: 22 February 2018 Accepted: 22 June 2018 Published: 16 July 2018

Citation:

Tong Y, Yu T, Li S, Zhao F, Ying J, Qu Y and Mu D (2018) Cumulative Evidence for Relationships Between 8q24 Variants and Prostate Cancer.

Front. Physiol. 9:915 doi: 10.3389/fphys.2018.00915

\section{Cumulative Evidence for Relationships Between 8q24 Variants and Prostate Cancer}

\author{
Yu Tong ${ }^{1,2 \dagger}$, Tao $Y u^{1,2+}$, Shiping $L^{1,2}$, Fengyan Zhao ${ }^{1,2}$, Junjie Ying ${ }^{1,2}, Y i Q u^{1,2}$ and \\ Dezhi $M u^{1,2 *}$
}

${ }^{1}$ Department of Pediatrics, West China Second University Hospital, Sichuan University, Chengdu, China, ${ }^{2}$ Key Laboratory of Obstetric \& Gynecologic and Pediatric Diseases and Birth Defects of Ministry of Education, West China Second University Hospital, Sichuan University, Chengdu, China

Multiple independent cancer susceptibility loci at chromosome $8 q 24$ have been identified by GWAS (Genome-wide association studies). Forty six articles including 60,293 cases and 62,971 controls were collected to conduct a meta-analysis to evaluate the associations between 21 variants in 8q24 and prostate cancer risk. Of the 21 variants located in 8q2\5 were significantly associated with the risk of prostate cancer. In particular, both homozygous AA and heterozygous CA genotypes of rs16901979, as well as the AA and CA genotypes of $r$ 1447295, were associated with the risk of prostate cancer. Our study showed that variants in the $8 \mathrm{q} 24$ region are associated with prostate cancer risk in this large-scale research synopsis and meta-analysis. Further studies are needed to explore the role of the 8q24 variants involved in the etiology of prostate cancer.

Keywords: 8q24, genetic variant, prostate cancer, susceptibility, meta-analysis

\section{INTRODUCTION}

Prostate cancer $(\mathrm{PCa})$ is the commonest non-cutaneous malignancy in men all over the world. Based on epidemiological and biological data, there is growing evidence that many influencing factors, including geography, ethnicity, genetic factors, and so on(Rebbeck, 2017), are associated with the risk of PCa. PCa exhibits high heritability, however, the exact etiology of PCa is still unknown. Identification of genetic factors regulating the susceptibility and progression of $\mathrm{PCa}$ contributes to improvement of preventive measures and therapeutic outcomes.

Multiple risk loci for prostate cancer have been identified by GWAS. In 2007, a two-stage GWAS from 1,854 prostate cancer patients and 1,894 population-screened controls was conducted. In this study, common loci at 8q24 were identified to be associated with prostate cancer (Eeles et al., 2008). It was proved that $8 \mathrm{q} 24$ region was associated with lots of cancers, including breast (Pereira et al., 2016), prostate (Hubbard et al., 2016), bladder (Kiltie, 2010), colon (Ling et al., 2013), lung (Zhang et al., 2012), gliomas (Rice et al., 2013), and so on. These susceptibility loci actually do not affect coding DNA, interestingly, these loci showed strong linkage disequilibrium (LD) as they often tightly linked with many SNPs. However, further study found that there are many enhancers in $8 \mathrm{q} 24$ region, and the rs6983267-containing enhancer interacts with the MYC gene by binding with TCF7L2 (TCF4), and alter the sensitivity to WNT signaling (Tuupanen et al., 2009). Another recent study found that the rs378854-containing region can interact with the promoters of both MYC and MYC activator PVT1(Meyer et al., 2011). Based on the above compelling evidence, it was supposed that the $8 \mathrm{q} 24$ variants played important roles in prostate carcinogenesis. 
Here we performed a comprehensive meta-analysis, involving a total of 60,293 cases and 62,971 controls, to evaluate all genetic studies that investigated associations between 15 variants in 8q24 and risk of prostate cancer.

\section{METHODS}

\section{Search Strategy and Selection Criteria}

We systematically searched PubMed and Embase to identify genetic association studies published in print or online before January 10th, 2018 in English language using key terms "8q24" and "polymorphism or variant or genotype" and "prostate carcinoma or prostate tumor or prostate cancer". Two investigators ( $\mathrm{Yu}$ Tong and Tao $\mathrm{Yu}$ ) independently assessed the eligibility of each study. All studies included in this meta-analysis must meet all the following inclusion criteria: (i) evaluating the associations of the $8 \mathrm{q} 24$ variants with prostate cancer risk; (ii) providing sufficient data or multivariate-adjusted risk estimates [e.g., odds ratios (ORs), hazard ratios (HRs), relative risks (RRs), 95\% confidence intervals (CIs) or standard errors (SEs)] to calculate these estimates. The exclusion criteria were as follows: (i) insufficient data; (ii) they were published as letters to editors or conference abstracts; (iii) they were studies about cancer mortality.

\section{Data Extraction}

Guidelines recommended were used to report meta-analyses of observational studies by an investigator ( $\mathrm{Yu}$ Tong and Tao $\mathrm{Yu})$ to extract data. Extracted data efrom each eligible study included name of first author, study design, publication date, source population, ethnicity, sample size, variants, alleles, and genotype counts, Hardy-Weinberg equilibrium (HWE) among controls. Ethnicity was classified as Caucasian, African, Asian, or others such as Latinos and Hawaiians. In this meta-analysis, 46 eligible publications are available with sufficient data.

\section{Statistical Analysis and Assessment of Cumulative Evidence}

For each study, the odds ratio (OR) was used as the metric of choice. Pooled odds ratios were computed by the fixed effects model and the random effects model based on heterogeneity estimates, according to Prof. Michael Borenstein's suggestion (Borenstein et al., 2010). Once an overall gene effect was confirmed, the genetic model-free approach suggested by Minelli et al. (2005) was used to estimate the genetic effects and mode of inheritance. Assessment of protection from bias also considered the magnitude of association. OR less than 1.15 implicated presence of bias, unless the association had been replicated prospectivelywith no evidence of publication bias by several studies, such as GWAS or GWAS meta-analysis from collaborative studies. Heterogeneity between studies was evaluated by Cochran's Q test and calculated $I^{2}$ statistic h. $I^{2}$-values $<25 \%, 25-50 \%$, and $>50 \%$ represent no or little heterogeneity, moderate heterogeneity, and large heterogeneity, respectively. Sensitivity analyses were conducted to examine if exclusion of first published study deviated from HWE in controls influence the significant association. Harbord's test was performed to evaluate publication bias. Small study bias was calculated by egger's test. All analyses were conducted using Stata, version 14.0 (StataCorp, 2017), with the metan, metabias commands.

\section{RESULTS}

\section{Eligible Studies}

Our initial database search identified 268 potentially relevant studies. Based on a review of titles and abstracts, 85 articles were retained. The full text of these 85 articles was reviewed in detail, and 46 studies were eligible in this meta-analysis. The specific process for identifying eligible studies and inclusion and exclusion criteria are summarized in Figure 1.

\section{Allelic Associations}

Of the 21 variants located in 8q24, 15 were significantly associated with the risk of prostate cancer, including rs16901979, rs1447295, rs6983561, rs7000448, rs6983267, rs13254738, rs7017300, rs7837688, rs1016343, rs7008482, rs4242384, rs620861, rs10086908, DG8S737 Allele-8, and rs10090154. No significant associations were found between rs4242382, rs4645959, rs7837328, rs16901966, rs10505476, rs13281615 and prostate cancer (data not shown).

\section{rs16901979 C>A}

Twenty-four studies were included (Table 1), and a significant association with prostate cancer risk was found $(p=1.08 \times$ $10^{-12}$, random effect $O R=1.48,95 \% C I: 1.33,1.65 ; Q=141.34$, $p=0.00, I^{2}=83.7 \%$, Figure 2A). A similar pattern was observed for Africans $\left(p=1.26 \times 10^{-26}\right.$, random effect $O R=1.33,95 \%$ $\left.C I: 1.26,1.40 ; Q=2.76, p=0.949, I^{2}=0.0 \%\right)$, Asians $(p=8.49$ $\times 10^{-5}$, random effect $O R=1.36,95 \% C I: 1.17,1.59 ; Q=12.31$, $\left.p=0.031, I^{2}=59.4 \%\right)$ and Caucasians $\left(p=6.48 \times 10^{-6}\right.$, random effect $O R=1.72,95 \% C I: 1.36,2.17 ; Q=50.60, p=0.00$, $\left.I^{2}=84.2 \%\right)$. No publication bias was found in the eligible studies (Harbord's test $p=0.757$, Table 2).

\section{rs1447295 C>A}

Thirty-seven studies were included (Table 1), a significant association was found with the risk of prostate cancer $(p=3.20$ $\times 10^{-14}$, random effect $O R=1.29,95 \% C I: 1.21,1.37 ; Q=160.1$, $p=0.00, I^{2}=77.5 \%$, Figure 2B).Significant association was also found for Asians $\left(p=2.08 \times 10^{-11}\right.$, random effect $O R=1.41$, 95\% CI: 1.27, 1.56; $\left.Q=7.77, p=0.354, I^{2}=9.9 \%\right)$ and Caucasians $\left(p=2.52 \times 10^{-23}\right.$, random effect $O R=1.41,95 \%$ $\left.C I: 1.31,1.50 ; Q=50.80, p=0.00, I^{2}=64.6 \%\right)$. However, no significant association was found for Africans $(p=0.168$, random effect $O R=1.05,95 \% C I: 0.98,1.11 ; Q=9.68, p=0.289$, $I^{2}=17.3 \%$ ), No publication bias was found in the eligible studies (Harbord's test $p=0.587$, Table 2).

\section{rs6983561 A>C}

Eleven studies were included (Table 1), a significant association was found with the risk of prostate cancer $(p=0.036$, random effect $O R=1.29,95 \% C I: 1.02,1.64 ; Q=128.51, p=0.00$, $I^{2}=92.2 \%$, Figure 2C). No significant association was found for 
Potential relevant studies identified and screened for retrieval $(\mathrm{N}=153)$

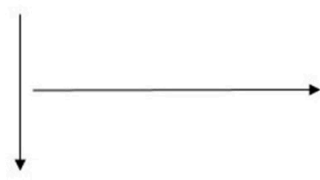

Studies have possible association $(\mathbf{N}=\mathbf{8 5})$

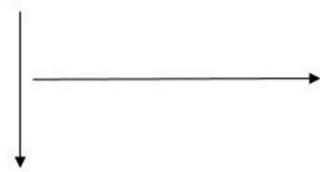
Studies included in this meta-analysis for $8 \mathrm{q} 2.4$ variants and human prostate and endometria cancers $(\mathrm{N}=46)$

Not related to the association between $8 \mathrm{q} 2.4$ variants and prostate cancer risk based on the title and abstracts $(\mathrm{N}=68)$

\section{Studies excluded $(\mathrm{N}=39)$ :}

Review articles $(\mathrm{N}=7)$

Patients only $\quad(\mathrm{N}=3)$

No data $\quad(\mathrm{N}=26)$

Tissue samples $(\mathrm{N}=3)$

FIGURE 1 | Flow diagram of included and excluded studies.

Africans $(p=0.269$, random effect $O R=1.17,95 \% C I$ : 0.88, 1.56; $\left.Q=21.67, p=0.000, I^{2}=86.2 \%\right)$ and Caucasians $(p=0.241$, random effect $O R=1.36,95 \% C I: 0.81,2.27 ; Q=105.31$, $\left.p=0.00, I^{2}=95.3 \%\right)$. No publication bias was found in the eligible studies (Harbord's test $p=0.977$, Table 2).

\section{rs7000448 C > T}

Eight studies were included (Table 1), a significant association was found with the risk of prostate cancer $(p=0.003$, random effect $O R=1.11,95 \% C I: 1.04,1.19 ; Q=9.41, p=0.152$, $I^{2}=36.2 \%$, Figure 2D). Further evaluation by ethnicity showed that significant association was found for Africans $(p=2.92 \times$ $10^{-5}$, random effect $O R=1.21,95 \% C I: 1.11,1.32 ; Q=1.82$, $\left.p=0.403, I^{2}=0.0 \%\right)$ and Caucasians $(p=0.018$, random effect $\left.O R=1.08,95 \% C I: 1.01,1.14 ; Q=3.18, p=0.37, I^{2}=5.6 \%\right)$. No publication bias was found in the eligible studies (Harbord's test $p=0.868$, Table 2).

\section{rs6983267 T>G}

Twenty-eight were included (Table 1), and a significant association with risk of prostate cancer was found $(p=0.003$, random effect $O R=1.15,95 \% C I: 1.05,1.25 ; Q=275.92$, $p=0.00, I^{2}=90.2 \%$, Figure $\left.2 \mathrm{E}\right)$. A similar pattern was observed for Asians $(p=0.003$, random effect $O R=1.13,95 \% C I$ : 1.04 , $\left.1.22 ; Q=4.35, p=0.501, I^{2}=0.0 \%\right)$ and Caucasians $(p=0.001$, random effect $O R=1.21,95 \% C I: 1.08,1.36 ; Q=189.54$, $\left.p=0.00, I^{2}=93.1 \%\right)$. No significant association was found for Africans $(p=0.269$, random effect $O R=0.98,95 \% C I: 0.68$, 1.42; $\left.Q=69.39, p=0.000, I^{2}=91.4 \%\right)$. No publication bias was found in the eligible studies (Harbord's test $p=0.577$, Table 2).

\section{rs13254738 A>C}

Six studies were included (Table 1), a significant association was found with the risk of prostate cancer $(p=0.026$, random effect $O R=1.11,95 \% C I: 1.01,1.22 ; Q=12.44, p=0.029, I^{2}=59.8 \%$, Figure 2F). Significant association was found for Caucasians $(p=0.08$, random effect $O R=1.06,95 \% C I: 0.99,1.14 ; Q=2.52$, $\left.p=0.47, I^{2}=0.0 \%\right)$. No publication bias was found in the eligible studies (Harbord's test $p=0.599$, Table 2).

\section{rs7017300 A>C}

Four studies were included, a significant association with prostate cancer risk was found $(p=0.001$, random effect $O R=1.39,95 \%$ $C I$ : 1.15, 1.68; $Q=17.93, p=0.000, I^{2}=83.3 \%$, Figure $2 G$ ). No publication bias was found in the eligible studies (Harbord's test $p=0.564$, Table 2).

\section{rs7837688 G > T}

Eight studies were included (Table 1), a significant association was found with the risk of prostate cancer $\left(p=1.66 \times 10^{-10}\right.$, random effect $O R=1.51,95 \% C I: 1.33,1.72 ; Q=35.02$, $p=0.000, I^{2}=80.0 \%$, Figure $\left.2 \mathbf{H}\right)$. Significant association was also found for Caucasians $\left(p=3.64 \times 10^{-9}\right.$, random effect $\left.O R=1.53,95 \% C I: 1.33,1.77 ; Q=26.07, p=0.000, I^{2}=80.8 \%\right)$. No publication bias was found in the eligible studies (Harbord's test $p=0.921$, Table 2 ).

\section{rs1016343 C> T}

Six studies were included (Table 1), a significant association with risk of prostate cancer was found $\left(p=8.25 \times 10^{-10}\right.$, random effect $O R=1.37,95 \% C I: 1.24,1.52 ; Q=20.42, p=0.001$, $I^{2}=75.5 \%$, Figure 2I). Significant association was also found for Caucasians $\left(p=3.64 \times 10^{-9}\right.$, random effect $O R=1.41,95 \%$ 
TABLE 1 | Characteristics of the included articles.

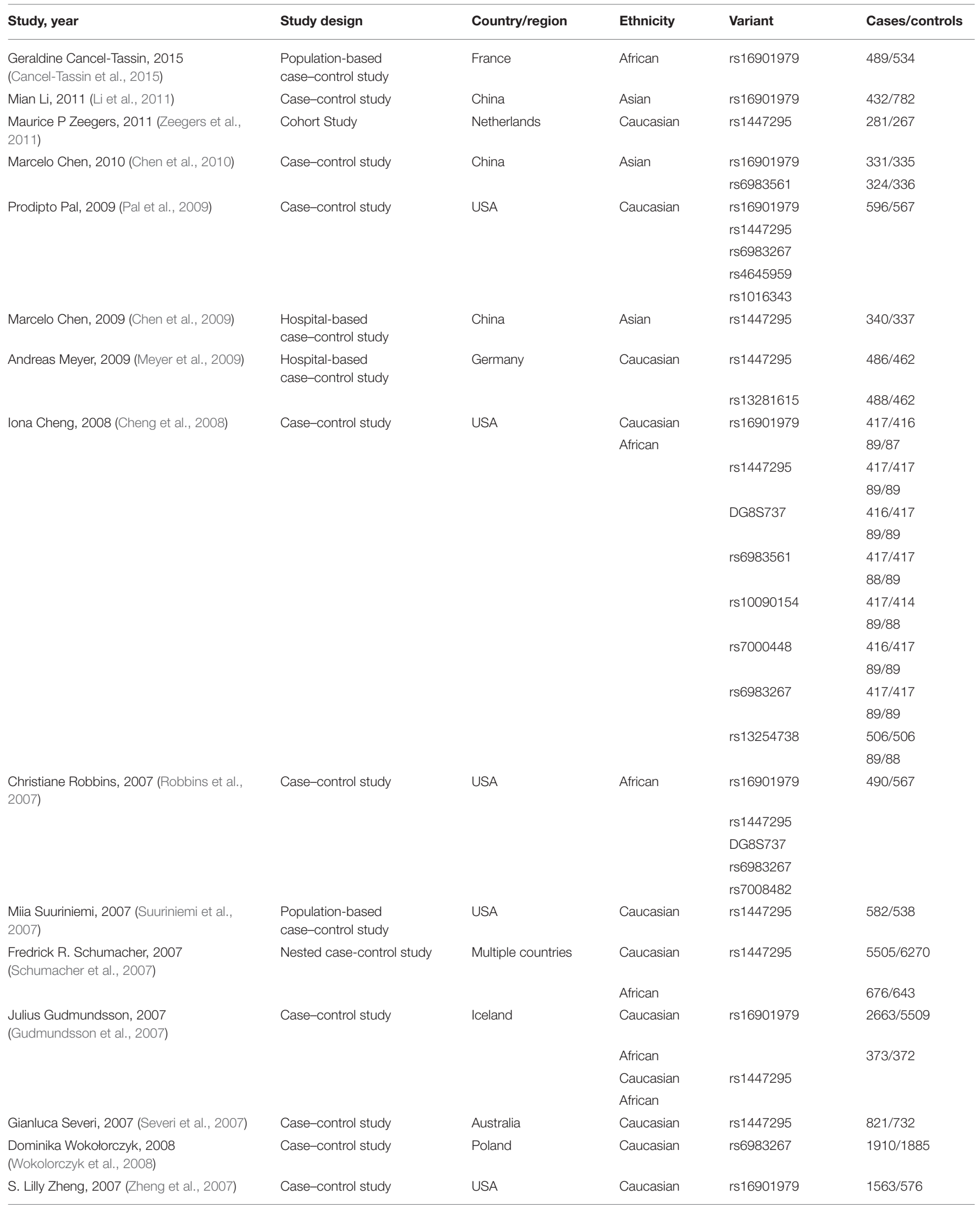


TABLE 1 | Continued

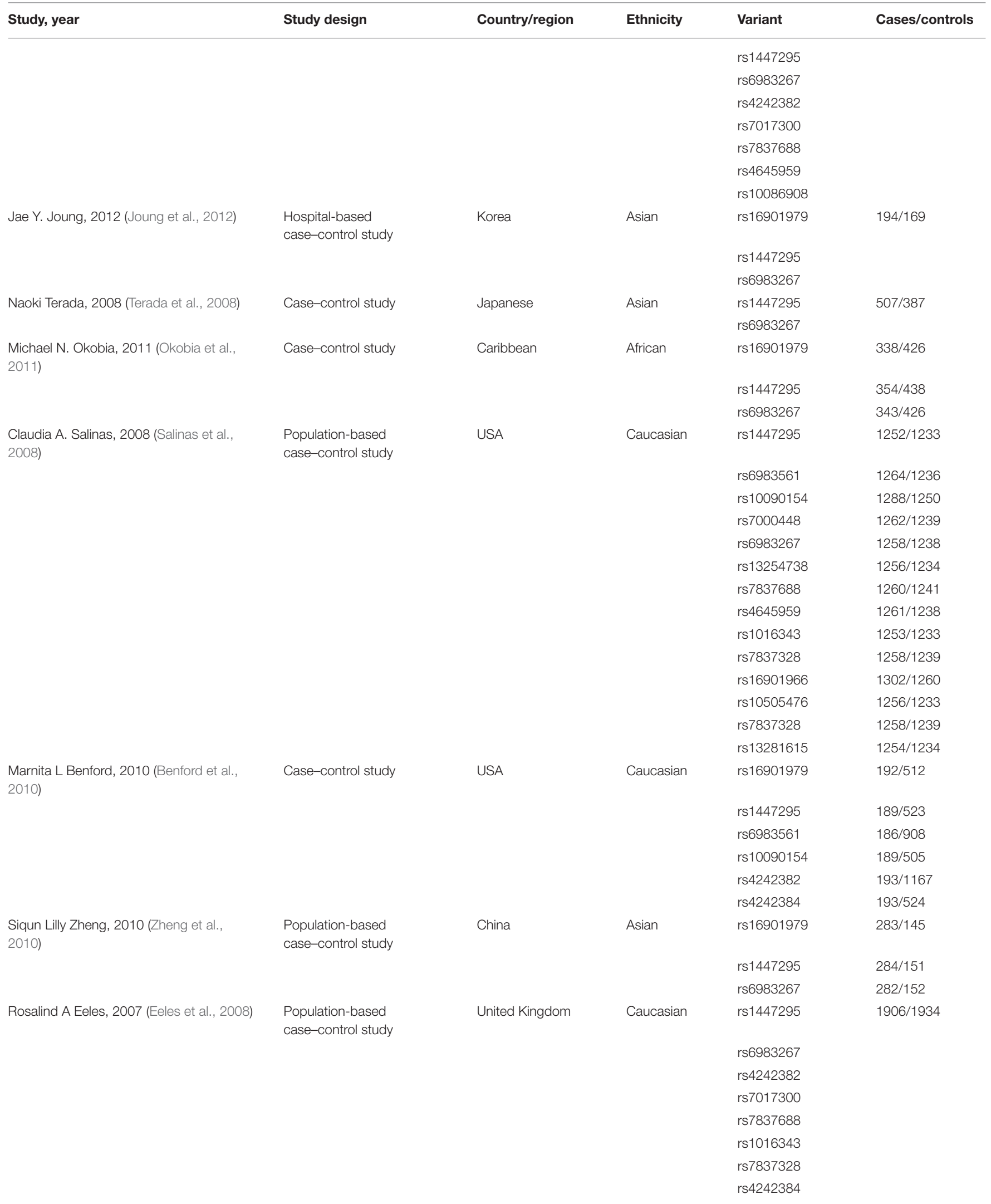


TABLE 1 | Continued

\begin{tabular}{|c|c|c|c|c|c|}
\hline Study, year & Study design & Country/region & Ethnicity & Variant & Cases/controls \\
\hline & & & & rs16901966 & \\
\hline \multirow[t]{7}{*}{ Jielin Sun, 2008 (Sun et al., 2008) } & $\begin{array}{l}\text { Population-based } \\
\text { case-control study }\end{array}$ & USA & Caucasian & rs16901979 & $1625 / 560$ \\
\hline & & & & rs1447295 & \\
\hline & & & & rs10090154 & \\
\hline & & & & rs7000448 & \\
\hline & & & & rs6983267 & \\
\hline & & & & rs13254738 & \\
\hline & & & & rs4242382 & \\
\hline \multirow{2}{*}{$\begin{array}{l}\text { Kathryn L. Penney, } 2009 \text { (Penney et al., } \\
\text { 2009) }\end{array}$} & Case-control study & USA & Caucasian & rs6983267 & $1305 / 1402$ \\
\hline & & & & rs13254738 & \\
\hline \multirow[t]{2}{*}{ Liang Wang, 2007 (Wang et al., 2007) } & Case-control study & USA & Caucasian & rs1447295 & $1121 / 545$ \\
\hline & & & & DG8S737 & \\
\hline \multirow[t]{4}{*}{ S. Lilly Zheng, 2008 (Zheng et al., 2008) } & $\begin{array}{l}\text { Population-based } \\
\text { case-control study }\end{array}$ & Sweden & Caucasian & rs16901979 & $2893 / 1781$ \\
\hline & & & & rs1447295 & \\
\hline & & & & rs6983561 & \\
\hline & & & & rs10090154 & \\
\hline Ying-Cai Tan, 2008 (Tan et al., 2008) & & & & rs6983267 & \\
\hline Viorel Jinga, 2016 (Jinga et al., 2016) & Case-control study & Romania & Caucasian & rs16901979 & $955 / 1007$ \\
\hline Cheryl D. Cropp, 2014 (Cropp et al., 2014) & $\begin{array}{l}\text { Population-based } \\
\text { case-control study }\end{array}$ & USA & Caucasian & rs7008482 & $522 / 510$ \\
\hline \multirow[t]{2}{*}{ Lin-Lin Zhang, 2014 (Zhang et al., 2014) } & Case-control study & China & Asian & rs7837328 & $388 / 384$ \\
\hline & & & & rs4242384 & \\
\hline \multirow{4}{*}{$\begin{array}{l}\text { Ignacio F. San Francisco, } 2014 \text { (San } \\
\text { Francisco et al., 2014) }\end{array}$} & Case-control study & Chile & Hispanic & rs1447295 & $83 / 21$ \\
\hline & & & & rs6983267 & \\
\hline & & & & rs7837328 & \\
\hline & & & & rs620861 & \\
\hline \multirow{6}{*}{$\begin{array}{l}\text { Adam B. Murphy, } 2012 \text { (Murphy et al., } \\
\text { 2012) }\end{array}$} & Case-control study & Cameroon & African & rs16901979 & $308 / 469$ \\
\hline & & & & rs1447295 & \\
\hline & & & & rs6983561 & \\
\hline & & & & rs7000448 & \\
\hline & & & & rs6983267 & \\
\hline & & & & rs7008482 & \\
\hline
\end{tabular}


TABLE 1 | Continued

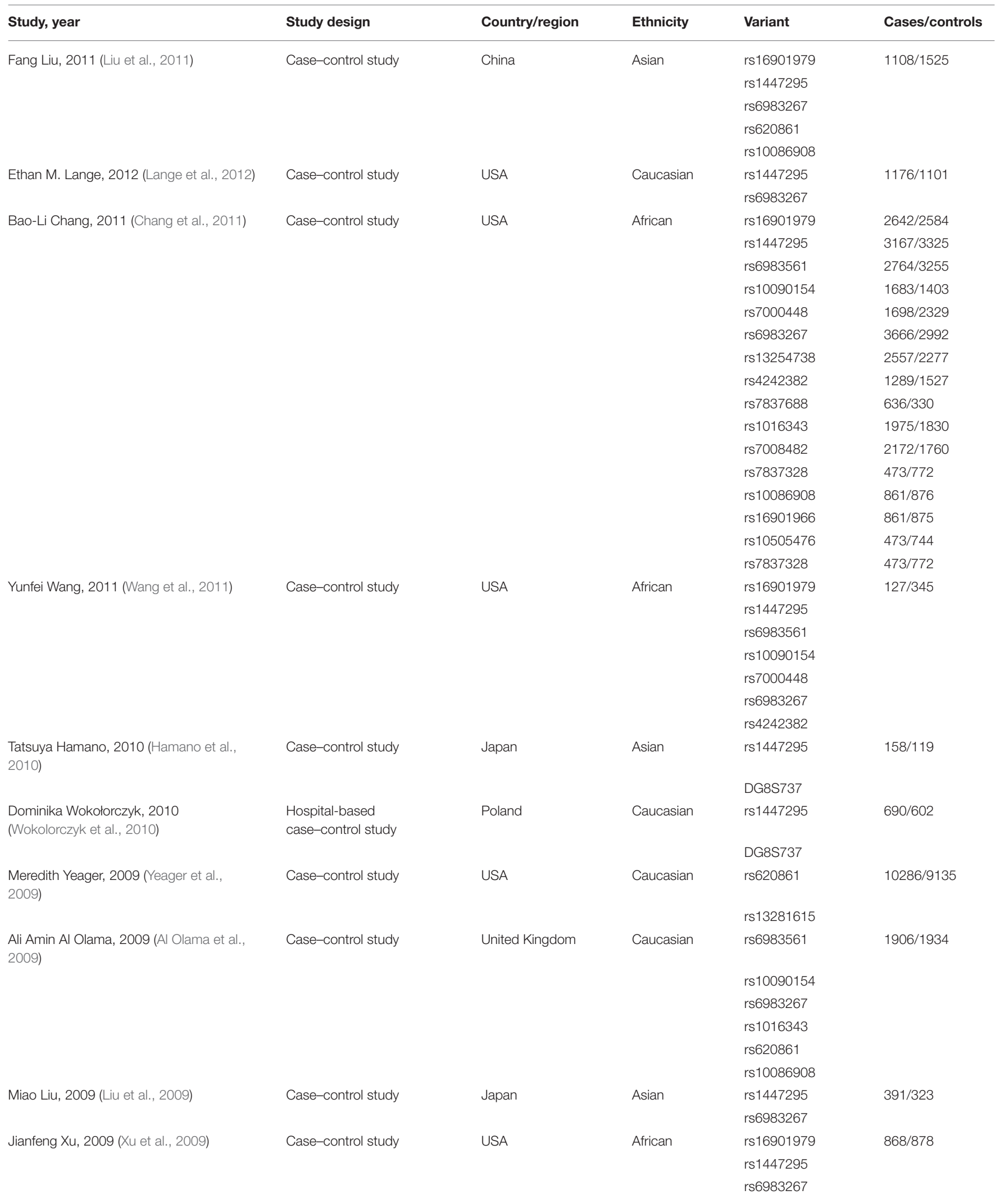


TABLE 1 | Continued

\begin{tabular}{|c|c|c|c|c|c|}
\hline Study, year & Study design & Country/region & Ethnicity & Variant & Cases/controls \\
\hline \multirow[t]{3}{*}{ Joke Beuten, 2009 (Beuten et al., 2009) } & Cohort Study & USA & Caucasian & rs10505476 & $601 / 840$ \\
\hline & & & hispanic & & $196 / 472$ \\
\hline & & & & rs7837328 & \\
\hline \multirow{3}{*}{$\begin{array}{l}\text { Meredith Yeager, } 2007 \text { (Yeager et al., } \\
\text { 2007) }\end{array}$} & Cohort Study & USA & Caucasian & rs1447295 & $4296 / 4299$ \\
\hline & & & & rs6983267 & \\
\hline & & & & rs7837688 & \\
\hline \multirow[t]{3}{*}{ Jong Jin Oh, 2017 (Oh et al., 2017) } & Hospital-based & & Caucasian & rs1016343 & $1001 / 2641$ \\
\hline & case-control study & & & & \\
\hline & & & & rs7837688 & \\
\hline \multirow[t]{4}{*}{ Haitao Chen, 2018 (Chen et al., 2018) } & Case-control study & & Caucasian & rs6983267 & $779 / 1643$ \\
\hline & & & & rs620861 & \\
\hline & & & & rs16901979 & \\
\hline & & & & rs1447295 & \\
\hline
\end{tabular}

$\left.C I: 1.32,1.50 ; Q=0.76, p=0.859, I^{2}=0.0 \%\right)$. No publication bias was found in the eligible studies (Harbord's test $p=0.922$, Table 2).

\section{rs7008482 G > T}

Four studies were included (Table 1), a significant association was found with the risk of prostate cancer $(p=0.021$, random effect $O R=0.77,95 \%$ CI: 0.62, 0.96; $Q=6.49, p=0.039$, $I^{2}=69.2 \%$, Figure 2J). No publication bias was found in the eligible studies (Harbord's test $p=0.549$, Table 2).

\section{rs4242384 A>C}

Three studies were included (Table 1), a significant association with prostate cancer risk was found $(p=0.022$, random effect $O R=1.42,95 \% C I: 1.02,1.92 ; Q=10.71, p=0.005, I^{2}=81.3 \%$, Figure $2 \mathrm{~K}$ ). No publication bias was found in the eligible studies (Harbord's test $p=0.376$, Table 2).

\section{rs620861 G>A}

Six studies were included (Table 1), a significant association was found with the risk of prostate cancer $\left(p=3.57 \times 10^{-4}\right.$, random effect $O R=0.86,95 \% C I: 0.79,0.94 ; Q=19.28, p=0.002$, $I^{2}=74.1 \%$, Figure 2L). Significant association was also found for Caucasians $\left(p=3.64 \times 10^{-9}\right.$, random effect $O R=0.84,95 \% C I$ : 0.77, 0.91; $\left.Q=13.34, p=0.004, I^{2}=77.5 \%\right)$. No publication bias was found in the eligible studies (Harbord's test $p=0.791$, Table 2).

\section{rs10086908 T>C}

Five studies were included (Table 1), a significant association was found with the risk of prostate cancer $\left(p=3.57 \times 10^{-4}\right.$, random effect $O R=0.73,95 \% C I: 0.60,0.88 ; Q=37.54, p=0.000$, $I^{2}=89.3 \%$, Figure $\left.2 \mathrm{M}\right)$. Significant association was also found for Caucasians $(p=0.036$, random effect $O R=0.70,95 \% C I$ : $\left.0.50,1.00 ; Q=37.13, p=0.004, I^{2}=94.6 \%\right)$. No publication bias was found in the eligible studies (Harbord's test $p=0.339$, Table 2).

\section{DG8S737 Allele-8 Absent>Present}

Five studies were included (Table 1), a significant association with risk of prostate cancer was found $\left(p=3.06 \times 10^{-4}\right.$, random effect $O R=1.29,95 \% C I: 1.12,1.47 ; Q=2.32, p=0.803$, $I^{2}=0.0 \%$, Figure $\left.2 \mathrm{~N}\right)$. A similar pattern was observed for Caucasians $(p=0.005$, random effect $O R=1.33,95 \% C I: 1.09$, 1.62; $\left.Q=1.91, p=0.386, I^{2}=0.0 \%\right)$. No publication bias was found in the eligible studies (Harbord's test $p=0.592$, Table 2).

\section{rs10090154 C>T}

Nine studies were included (Table 1), a significant association was found with the risk of prostate cancer $\left(p=2.04 \times 10^{-5}\right.$, random effect $O R=1.33,95 \% C I: 1.17,1.52 ; Q=0.70, p=0.873$, $I^{2}=0.0 \%$, Figure 20). A similar pattern was observed for Caucasians $\left(p=3.63 \times 10^{-5}\right.$, random effect $O R=1.33,95 \%$ $\left.C I: 1.16,1.52 ; Q=0.70, p=0.705, I^{2}=0.0 \%\right)$. No publication bias was found in the eligible studies (Harbord's test $p=0.641$, Table 2).

\section{GENOTYPE COMPARISON}

\section{rs16901979 C>A}

Of the 24 studies, nine reported genotype information. The effects of genotype for AA vs. CC (OR1) and CA vs. CC $(O R 2)$ were calculated. Multivariate meta-analysis was conducted to estimate the pooled risk (Table 2). Individuals with the homozygous AA genotype $\left(p=3.86 \times 10^{-9}\right.$, random effect $\left.O R 1=1.71,95 \% C I: 1.43,2.04 ; Q=7.48, p=0.486, I^{2}=0.0 \%\right)$ and heterozygous CA genotype $\left(p=3.06 \times 10^{-4}\right.$, random effect $\left.O R 2=1.36,95 \% C I: 1.15,1.61 ; Q=14.29, p=0.074, I^{2}=44.0 \%\right)$ have increased risk of prostate cancer.

\section{rs1447295 C>A}

Of the 38 studies, 19 reported genotype information. The effects of genotype for AA vs. CC (OR1) and CA vs. CC (OR2) were calculated for each study (Table 2). Individuals with the homozygous AA genotype $(p=0.006$, random effect $O R 1=1.42$, 

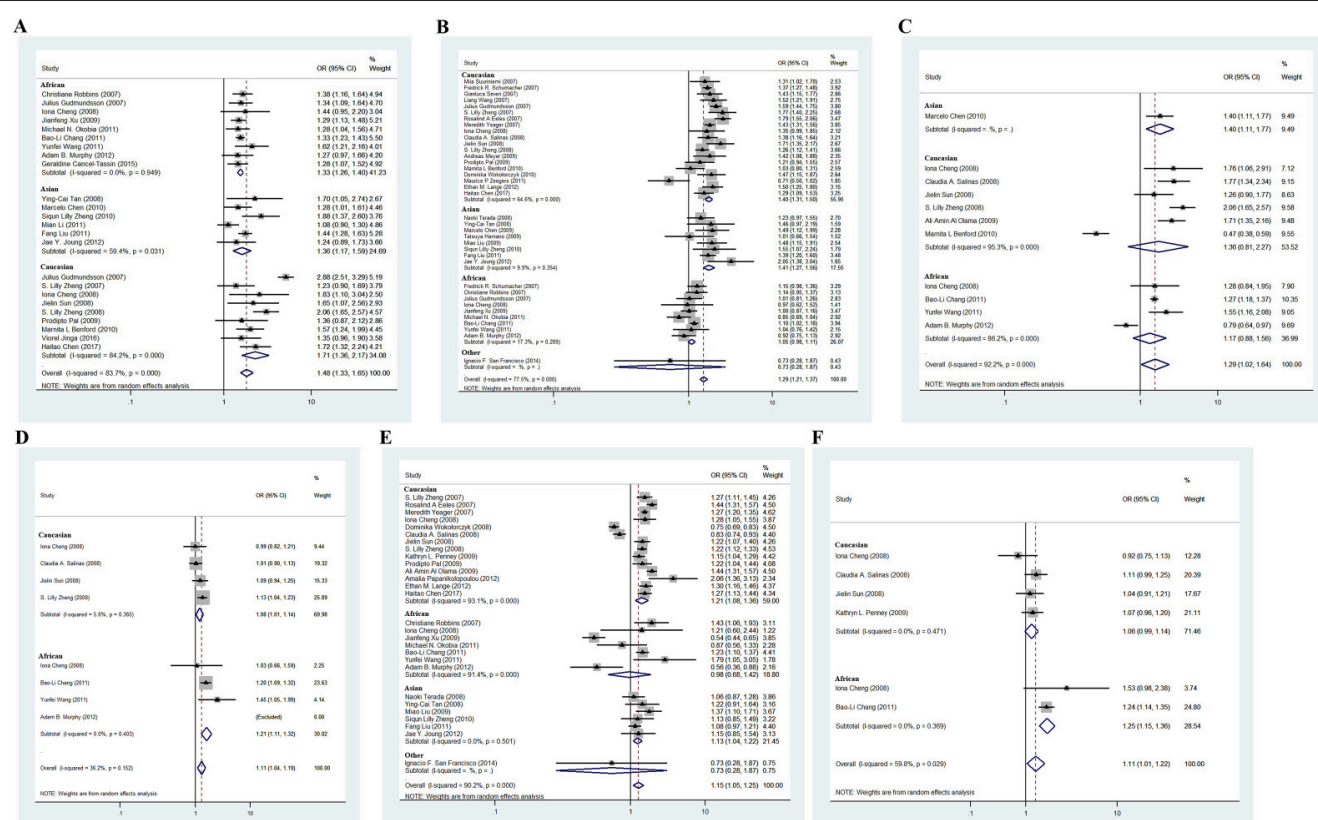

$\mathbf{E}$

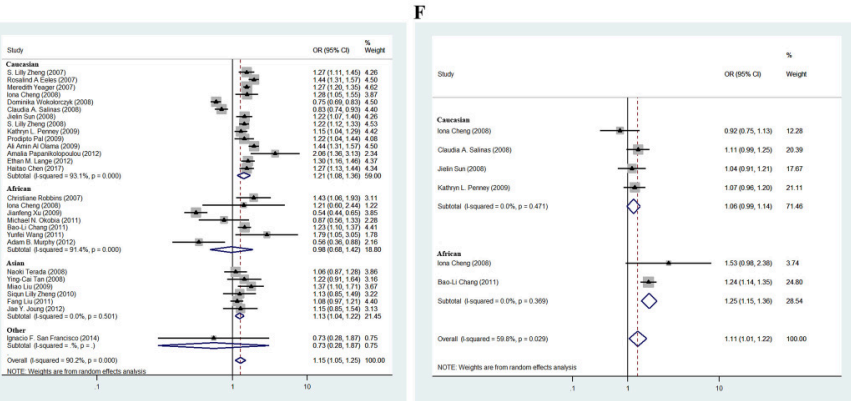

G

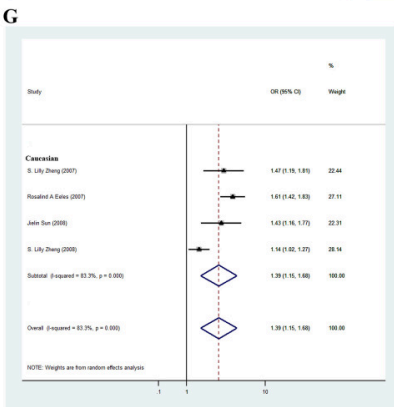

$\mathbf{J}$
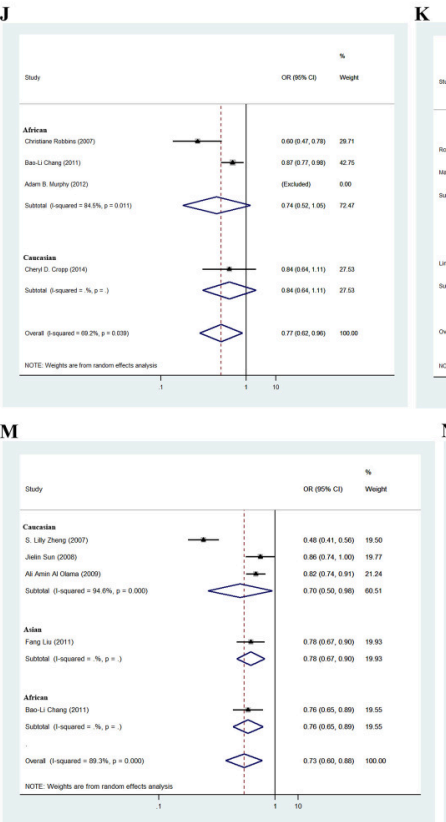

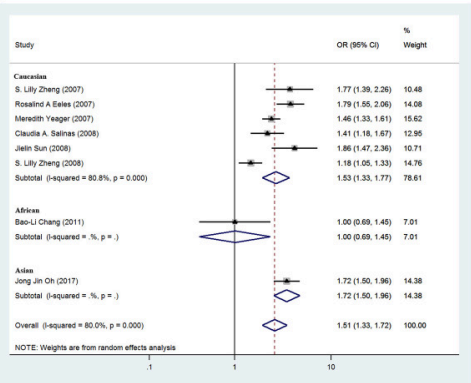

I
K

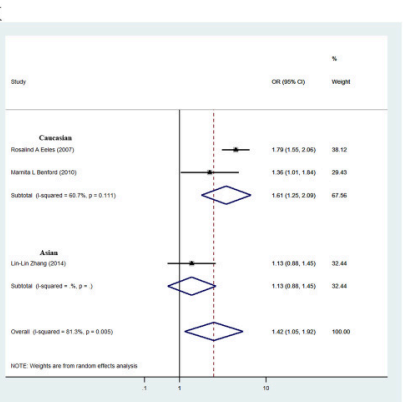

N

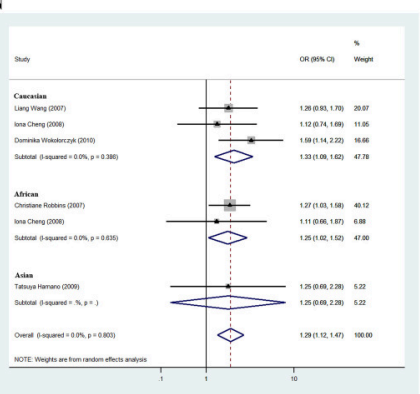

$\mathbf{L}$
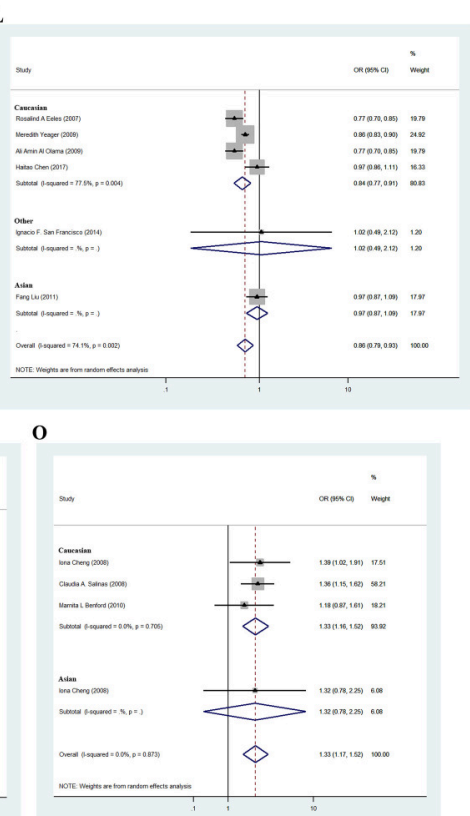

FIGURE 2 | Forest plots for associations between selected variants in the 8q24 region and prostate cancer risk. Associations of rs16901979 (A), rs1447295 (B), rs6983561 (C), rs7000448 (D), rs6983267 (E), rs13254738 (F), rs7017300 (G), rs7837688 (H), rs1016343 (I), rs7008482 (J), rs4242384 (K), rs620861 (L), rs10086908 (M), DG8S737 Allele-8 (N), and rs10090154 (O) with prostate cancer risk. 


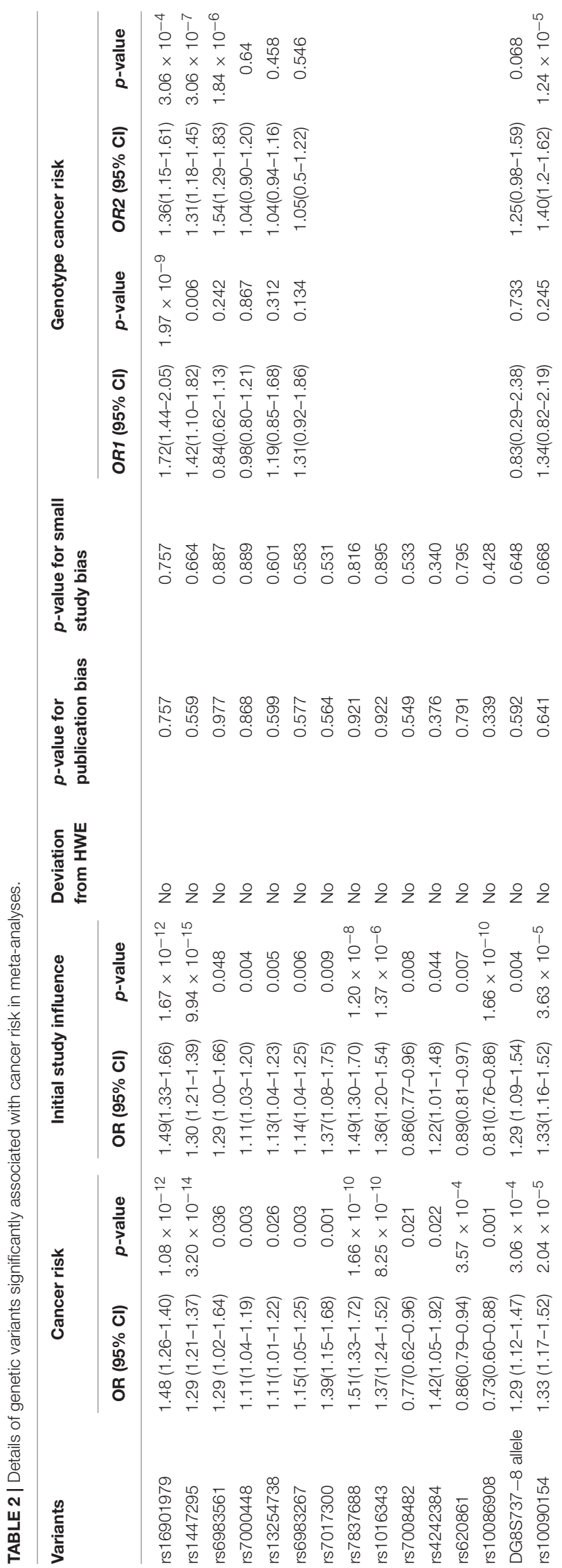

95\% CI: 1.10, 1.82; $\left.Q=33.56, p=0.010, I^{2}=49.3 \%\right)$ and heterozygous $\mathrm{CA}$ genotype $\left(p=3.06 \times 10^{-7}\right.$, random effect $\left.O R 2=1.31,95 \% C I: 1.18,1.45 ; Q=38.05, p=0.002, I^{2}=55.3 \%\right)$ have increased risk of prostate cancer.

\section{rs6983561 A>C}

Of the 11 studies, five reported genotype information. The genotype effects for CC vs. AA (OR1) and AC vs. AA (OR2) were calculated for each study (Table 2). There was a significantly increased risk of prostate cancer among individuals with heterozygous AC genotype $\left(p=1.84 \times 10^{-6}\right.$, random effect $O R 2=1.54,95 \%$ CI: $\left.1.29,1.83 ; Q=4.10, p=0.393, I^{2}=2.4 \%\right)$. However, no significant association was found among individuals with the homozygous CC genotype.

\section{rs10090154 C>T}

Of the 9 studies, four reported genotype information. The effects of genotype for TT vs. CC (OR1) and CT vs. CC $(O R 2)$ were calculated for each study (Table 2). Individuals with heterozygous CT genotype $\left(p=1.24 \times 10^{-5}\right.$, random effect $\left.O R 2=1.40,95 \% C I: 1.20,1.62 ; Q=1.58, p=0.663, I^{2}=0.0 \%\right)$ have an increased risk of prostate cancer. However, no significant association was found among individuals with the homozygous TT genotype.

\section{SENSITIVITY ANALYSIS}

Results of sensitivity analysis showed that the obtained results of $8 \mathrm{q} 24$ variants and risk of prostate cancer were robust statistically and no individual study affected the pooled OR significantly (Table 2).

\section{DISCUSSION}

To our knowledge, this study is the most comprehensive and largest evaluation of publications on associations between 8q24 variants and PCa risk. Preliminary meta-analyses mostly focused on the association between single or less SNPs with prostate cancer. From 46 eligible articles including 60,293 cases and 62,971 controls, we performed meta-analysis to evaluate associations between 15 variants in $8 \mathrm{q} 24$ region and PCa risk. Our study here provides an update of the previous reports. In addition, more variants were evaluated that have not been analyzed by meta-analyses previously.

Of the 21 variants located in 8q24, 15 were associated with prostate cancer risk significantly. Our primary analysis shows that, the $\operatorname{rs} 16901979\left(p=1.08 \times 10^{-12}, O R=1.48\right)$, rs1447295 $\left(p=4.51 \times 10^{-15}, O R=1.29\right)$, rs6983561 $(p=0.036$, $O R=1.29), r s 7000448(p=0.003, O R=1.11), r s 6983267$ $(p=0.003, O R=1.15), r s 13254738(p=0.026, O R=1.11)$, rs7017300 $(p=0.001, O R=1.39)$, rs7837688 $(p=1.66 \times$ $\left.10^{-10}, O R=1.51\right), \operatorname{rs} 1016343\left(p=8.25 \times 10^{-10}, O R=1.37\right)$, rs7008482 $(p=0.021, O R=0.77), \operatorname{rs} 4242384(p=0.022$, $O R=1.42), \quad r s 620861\left(p=3.57 \times 10^{-4}, O R=0.86\right)$, rs10086908 $\left(p=3.57 \times 10^{-4}, O R=0.73\right)$, DG8S737 Allele$8\left(p=3.06 \times 10^{-4}, O R=1.29\right), \operatorname{rs} 10090154(p=2.04 \times$ 
$\left.10^{-5}, O R=1.33\right)$ were significantly associated with PCa risk. In particular, both homozygous AA $\left(p=3.86 \times 10^{-9}\right.$, OR $\left.1=1.71\right)$ and heterozygous CA $\left(p=3.06 \times 10^{-4}, O R 2=1.36\right)$ genotypes of rs16901979, as well as the AA $(p=0.005, O R 1=1.41)$ and CA $\left(p=2.14 \times 10^{-8}\right.$, OR2 $\left.=1.33\right)$ genotypes of rs1447295, were associated with PCa risk. Heterozygous AC genotype $(p=1.84$ $\times 10^{-7}$, OR2 $\left.=1.54\right)$ of rs6983561, CT genotype $(p=1.24 \times$ $10^{-5}, O R 2=1.40$ ) of rs 10090154 were also found to be associated with the risk of PCa. Our findings were robust in regard to study design and sensitivity analyses according to several genevariants-association studies and thousands of participants. No evidence of small study bias or publication bias was found.

The $8 \mathrm{q} 24$ region is dense with SNP (single-nucleotidepolymorphism) associated with risk for prostate, colorectal, breast cancer, et al. There are about five separated different cancer susceptibility loci specific for different cancers within the 8q24 “desert" (Huppi et al., 2012). Region 1, including rs16901979, rs13254738 and rs6983561, region 4, including rs7000448 and region 5, including rs1447295 specifically associated with the PCa risk, rs13281615 in region 2 is a breast-specific cancer susceptibility loci, rs10505477 and rs10808556 in a same block in region 3 were confirmed to be associated with colorectal cancer(Ghoussaini et al., 2008). Although the exact biological mechanisms underlying these associations with multiple cancers are confusing, these variants might affect tissue-specific enhancers of one or more genes involved in carcinogenesis. FAM84B, very closest to $8 \mathrm{q} 24$, is reported that, during prostate tumorigenesis and follows $\mathrm{PCa}$ progression, its

\section{REFERENCES}

Al Olama, A. A., Kote-Jarai, Z., Giles, G. G., Guy, M., Morrison, J., Severi, G., et al. (2009). Multiple loci on 8q24 associated with prostate cancer susceptibility. Nat. Genet. 41, 1058-1060. doi: 10.1038/ng.452

Benford, M. L., VanCleave, T. T., Lavender, N. A., Kittles, R. A., and Kidd, L. R. (2010). 8q24 sequence variants in relation to prostate cancer risk among men of African descent: a case-control study. BMC Cancer 10:334. doi: 10.1186/1471-2407-10-334

Beuten, J., Gelfond, J. A., Martinez-Fierro, M. L., Weldon, K. S., Crandall, A. C., Rojas-Martinez, A., et al. (2009). Association of chromosome 8q variants with prostate cancer risk in Caucasian and Hispanic men. Carcinogenesis 30, 1372-1379. doi: 10.1093/carcin/bgp148

Borenstein, M., Hedges, L. V., Higgins, J. P., and Rothstein, H. R. (2010). A basic introduction to fixed-effect and random-effects models for meta-analysis. Res. Synth. Methods 1, 97-111. doi: 10.1002/jrsm.12

Cancel-Tassin, G., Romana, M., Gaffory, C., Blanchet, P., Cussenot, O., and Multigner, L. (2015). Region 2 of $8 \mathrm{q} 24$ is associated with the risk of aggressive prostate cancer in Caribbean men of African descent from Guadeloupe (French West Indies). Asian J. Androl. 17, 117-119. doi: 10.4103/1008-682X. 135127

Chang, B. L., Spangler, E., Gallagher, S., Haiman, C. A., Henderson, B., Isaacs, W., et al. (2011). Validation of genome-wide prostate cancer associations in men of African descent. Cancer Epidemiol. Biomarkers Prev. 20, 23-32. doi: 10.1158/1055-9965.EPI-10-0698

Chen, H., Ewing, C. M., Zheng, S., Grindedaal, E. M., Cooney, K. A., Wiley, K., et al. (2018). Genetic factors influencing prostate cancer risk in Norwegian men. Prostate 78, 186-192. doi: 10.1002/pros.23453

Chen, M., Huang, Y. C., Ko, I. L., Yang, S., Chang, Y. H., Huang, W. J., et al. (2009). The rs1447295 at $8 \mathrm{q} 24$ is a risk variant for prostate cancer in Taiwanese men. Urology 74, 698-701. doi: 10.1016/j.urology.2009.02.035 expression increased (Wong et al., 2017). Another pseudogene of POU5F1P1/POU5F1B, located in 8q24.21 region, was also observed that levels of both the mRNA and protein increased in PCa (Kastler et al., 2010). Therefore, variants in 8q24 region themselves or with other variants might be responsible for the associations with prostate cancer.

Our study provides summary evidence that common 15 variants in the $8 \mathrm{q} 24$ region are associated with $\mathrm{PCa}$ risk. To explore the exact mechanisms of $8 \mathrm{q} 24$ variants involved in parthenogenesis of prostate cancer needs further functional studies.

\section{AUTHOR CONTRIBUTIONS}

Data were extracted by YT and TY. SL, FZ, and JY analyzed the data. YQ and DM wrote the manuscript.

\section{ACKNOWLEDGMENTS}

This work was supported by the National Natural Science Foundation of China (No. 81401238, 81330016, 81630038, 81771634), grants from the Ministry of Education of China (313037, 20110181130002), a grant from State Commission of Science Technology of China (2012BAI04B04), grants from the Science and Technology Bureau of Sichuan province (2012SZ0010, 2014SZ0149, 2016JY0028), and a grant from the clinical discipline program (Neonatology) from the Ministry of Health of China (1311200003303).
Chen, M., Huang, Y. C., Yang, S., Hsu, J. M., Chang, Y. H., Huang, W. J., et al. (2010). Common variants at $8 \mathrm{q} 24$ are associated with prostate cancer risk in Taiwanese men. Prostate 70, 502-507. doi: 10.1002/pros.21084

Cheng, I., Plummer, S. J., Jorgenson, E., Liu, X., Rybicki, B. A., Casey, G., et al. (2008). 8q24 and prostate cancer: association with advanced disease and meta-analysis. Eur. J. Hum. Genet. 16, 496-505. doi: 10.1038/sj.ejhg.520 1959

Cropp, C. D., Robbins, C. M., Sheng, X., Hennis, A. J., Carpten, J. D., Waterman, L., et al. (2014). 8q24 risk alleles and prostate cancer in African-Barbadian men. Prostate 74, 1579-1588. doi: 10.1002/pros.22871

Eeles, R. A., Kote-Jarai, Z., Giles, G. G., Olama, A. A., Guy, M., Jugurnauth, S. K., et al. (2008). Multiple newly identified loci associated with prostate cancer susceptibility. Nat. Genet. 40, 316-321. doi: 10.1038/ng.90

Ghoussaini, M., Song, H., Koessler, T., Al Olama, A. A., Kote-Jarai, Z., Driver, K. E., et al. (2008). Multiple loci with different cancer specificities within the 8q24 gene desert. J. Natl. Cancer Inst. 100, 962-966. doi: 10.1093/jnci/djn190

Gudmundsson, J., Sulem, P., Manolescu, A., Amundadottir, L. T., Gudbjartsson, D., Helgason, A., et al. (2007). Genome-wide association study identifies a second prostate cancer susceptibility variant at 8q24. Nat. Genet. 39, 631-637. doi: 10.1038/ng1999

Hamano, T., Matsui, H., Sekine, Y., Ohtake, N., Nakata, S., and Suzuki, K. (2010). Association of SNP rs1447295 and microsatellite marker DG8S737 with familial prostate cancer and high grade disease. J. Urol. 184, 738-742. doi: 10.1016/j.juro.2010.03.102

Hubbard, G. K., Mutton, L. N., Khalili, M., McMullin, R. P., Hicks, J. L., BianchiFrias, D., et al. (2016). Combined MYC activation and pten loss are sufficient to create genomic instability and lethal metastatic prostate cancer. Cancer Res. 76, 283-292. doi: 10.1158/0008-5472.CAN-14-3280

Huppi, K., Pitt, J. J., Wahlberg, B. M., and Caplen, N. J. (2012). The 8q24 gene desert: an oasis of non-coding transcriptional activity. Front. Genet. 3:69. doi: 10.3389/fgene.2012.00069 
Jinga, V., Csiki, I. E., Manolescu, A., Iordache, P., Mates, I. N., Radavoi, D., et al. (2016). Replication study of 34 common SNPs associated with prostate cancer in the Romanian population. J. Cell. Mol. Med. 20, 594-600. doi: $10.1111 /$ jcmm.12729

Joung, J. Y., Park, S., Yoon, H., Lee, S. J., Park, W. S., Seo, H. K., et al. (2012). Association of common variations of $8 \mathrm{q} 24$ with the risk of prostate cancer in Koreans and a review of the Asian population. BJU Int. 110(6 Pt B), E318-E325. doi: 10.1111/j.1464-410X.2012.11211.x

Kastler, S., Honold, L., Luedeke, M., Kuefer, R., Möller, P., Hoegel, J., et al. (2010). POU5F1P1, a putative cancer susceptibility gene, is overexpressed in prostatic carcinoma. Prostate 70, 666-674. doi: 10.1002/pros.21100

Kiltie, A. E. (2010). Common predisposition alleles for moderately common cancers: bladder cancer. Curr. Opin. Genet. Dev. 20, 218-224. doi: 10.1016/j.gde.2010.01.002

Lange, E. M., Salinas, C. A., Zuhlke, K. A., Ray, A. M., Wang, Y., Lu, Y., et al. (2012). Early onset prostate cancer has a significant genetic component. Prostate 72, 147-156. doi: 10.1002/pros.21414

Li, M., Zhou, Y., Chen, P., Yang, H., Yuan, X., Tajima, K., et al. (2011). Genetic variants on chromosome $8 \mathrm{q} 24$ and colorectal neoplasia risk: a case-control study in China and a meta-analysis of the published literature. PLoS ONE 6:e18251. doi: 10.1371/journal.pone.0018251

Ling, H., Spizzo, R., Atlasi, Y., Nicoloso, M., Shimizu, M., Redis, R. S., et al. (2013). CCAT2, a novel noncoding RNA mapping to 8q24, underlies metastatic progression and chromosomal instability in colon cancer. Genome Res. 23, 1446-1461. doi: 10.1101/gr.152942.112

Liu, F., Hsing, A. W., Wang, X., Shao, Q., Qi, J., Ye, Y., et al. (2011). Systematic confirmation study of reported prostate cancer risk-associated single nucleotide polymorphisms in Chinese men. Cancer Sci. 102, 1916-1920. doi: 10.1111/j.1349-7006.2011.02036.x

Liu, M., Kurosaki, T., Suzuki, M., Enomoto, Y., Nishimatsu, H., Arai, T., et al. (2009). Significance of common variants on human chromosome 8q24 in relation to the risk of prostate cancer in native Japanese men. BMC Genet. 10:37. doi: 10.1186/1471-2156-10-37

Meyer, A., Schürmann, P., Ghahremani, M., Kocak, E., Brinkhaus, M. J., Bremer, M., et al. (2009). Association of chromosomal locus 8q24 and risk of prostate cancer: a hospital-based study of German patients treated with brachytherapy. Urol. Oncol. 27, 373-376. doi: 10.1016/j.urolonc.2008.04.010

Meyer, K. B., Maia, A. T., O’Reilly, M., Ghoussaini, M., Prathalingam, R., PorterGill, P., et al. (2011). A functional variant at a prostate cancer predisposition locus at $8 \mathrm{q} 24$ is associated with PVT1 expression. PLoS Genet. 7:e1002165. doi: 10.1371 /journal.pgen.1002165

Minelli, C., Thompson, J. R., Abrams, K. R., and Lambert, P. C. (2005). Bayesian implementation of a genetic model-free approach to the meta-analysis of genetic association studies. Stat. Med. 24, 3845-3861. doi: 10.1002/sim.2393

Murphy, A. B., Ukoli, F., Freeman, V., Bennett, F., Aiken, W., Tulloch, T., et al. (2012). 8q24 risk alleles in West African and Caribbean men. Prostate 72, 1366-1373. doi: $10.1002 /$ pros.22486

Oh, J. J., Lee, S. J., Hwang, J. Y., Kim, D., Lee, S. E., Hong, S. K., et al. (2017). Exomebased genome-wide association study and risk assessment using genetic risk score to prostate cancer in the Korean population. Oncotarget 8, 43934-43943. doi: 10.18632/oncotarget.16540

Okobia, M. N., Zmuda, J. M., Ferrell, R. E., Patrick, A. L., and Bunker, C. H. (2011). Chromosome 8q24 variants are associated with prostate cancer risk in a high risk population of African ancestry. Prostate 71, 1054-1063. doi: $10.1002 /$ pros. 21320

Pal, P., Xi, H., Guha, S., Sun, G., Helfand, B. T., Meeks, J. J., et al. (2009). Common variants in $8 \mathrm{q} 24$ are associated with risk for prostate cancer and tumor aggressiveness in men of European ancestry. Prostate 69, 1548-1556. doi: $10.1002 /$ pros.20999

Papanikolopoulou, A., Landt, O., Ntoumas, K., Bolomitis, S., Tyritzis, S. I., Constantinides, C., et al. (2011). The multi-cancer marker, rs6983267, located at region 3 of chromosome 8q24, is associated with prostate cancer in Greek patients but does not contribute to the aggressiveness of the disease. Clin. Chem. Lab. Med. 50, 379-385. doi: 10.1515/CCLM.2011.778

Penney, K. L., Salinas, C. A., Pomerantz, M., Schumacher, F. R., Beckwith, C. A., Lee, G. S., et al. (2009). Evaluation of $8 \mathrm{q} 24$ and $17 \mathrm{q}$ risk loci and prostate cancer mortality. Clin. Cancer Res. 15, 3223-3230. doi: 10.1158/1078-0432.CCR-08-2733
Pereira, B., Chin, S. F., Rueda, O. M., Vollan, H. K., Provenzano, E., Bardwell, H. A., et al. (2016). The somatic mutation profiles of 2,433 breast cancers refines their genomic and transcriptomic landscapes. Nat. Commun. 7:11479. doi: $10.1038 /$ ncomms11479

Rebbeck, T. R. (2017). Prostate cancer genetics: variation by race, ethnicity, and geography. Semin. Radiat. Oncol. 27, 3-10. doi: 10.1016/j.semradonc.2016.08.002

Rice, T., Zheng, S., Decker, P. A., Walsh, K. M., Bracci, P., Xiao, Y., et al. (2013). Inherited variant on chromosome 11q23 increases susceptibility to IDH-mutated but not IDH-normal gliomas regardless of grade or histology. Neuro-oncology 15, 535-541. doi: 10.1093/neuonc/nos324

Robbins, C., Torres, J. B., Hooker, S., Bonilla, C., Hernandez, W., Candreva, A., et al. (2007). Confirmation study of prostate cancer risk variants at 8q24 in African Americans identifies a novel risk locus. Genome Res. 17, 1717-1722. doi: 10.1101/gr.6782707

Salinas, C. A., Kwon, E., Carlson, C. S., Koopmeiners, J. S., Feng, Z., Karyadi, D. M., et al. (2008). Multiple independent genetic variants in the $8 \mathrm{q} 24$ region are associated with prostate cancer risk. Cancer Epidemiol. Biomarkers Prev. 17, 1203-1213. doi: 10.1158/1055-9965.EPI-07-2811

San Francisco, I. F., Rojas, P. A., Torres-Estay, V., Smalley, S., Cerda-Infante, J., Montecinos, V. P., et al. (2014). Association of RNASEL and 8q24 variants with the presence and aggressiveness of hereditary and sporadic prostate cancer in a Hispanic population. J. Cell. Mol. Med. 18, 125-133. doi: 10.1111/jcmm.12171

Schumacher, F. R., Feigelson, H. S., Cox, D. G., Haiman, C. A., Albanes, D., Buring, J., et al. (2007). A common 8q24 variant in prostate and breast cancer from a large nested case-control study. Cancer Res. 67, 2951-2956. doi: 10.1158/0008-5472.CAN-06-3591

Severi, G., Hayes, V. M., Padilla, E. J., English, D. R., Southey, M. C., Sutherland, R. L., et al. (2007). The common variant rs1447295 on chromosome $8 \mathrm{q} 24$ and prostate cancer risk: results from an Australian populationbased case-control study. Cancer Epidemiol. Biomarkers Prev. 16, 610-612. doi: 10.1158/1055-9965.EPI-06-0872

Sun, J., Lange, E. M., Isaacs, S. D., Liu, W., Wiley, K. E., Lange, L., et al. (2008). Chromosome $8 \mathrm{q} 24$ risk variants in hereditary and non-hereditary prostate cancer patients. Prostate 68, 489-497. doi: 10.1002/pros.20695

Suuriniemi, M., Agalliu, I., Schaid, D. J., Johanneson, B., McDonnell, S. K., Iwasaki, L., et al. (2007). Confirmation of a positive association between prostate cancer risk and a locus at chromosome 8q24. Cancer Epidemiol. Biomarkers Prev. 16 809-814. doi: 10.1158/1055-9965.EPI-06-1049

Tan, Y. C., Zeigler-Johnson, C., Mittal, R. D., Mandhani, A., Mital, B., Rebbeck, T. R., et al. (2008). Common 8q24 sequence variations are associated with Asian Indian advanced prostate cancer risk. Cancer Epidemiol. Biomarkers Prev. 17, 2431-2435. doi: 10.1158/1055-9965.EPI-07-2823

Terada, N., Tsuchiya, N., Ma, Z., Shimizu, Y., Kobayashi, T., Nakamura, E., et al. (2008). Association of genetic polymorphisms at $8 \mathrm{q} 24$ with the risk of prostate cancer in a Japanese population. Prostate 68, 1689-1695. doi: $10.1002 /$ pros. 20831

Tuupanen, S., Turunen, M., Lehtonen, R., Hallikas, O., Vanharanta, S., Kivioja, T., et al. (2009). The common colorectal cancer predisposition SNP rs6983267 at chromosome $8 \mathrm{q} 24$ confers potential to enhanced Wnt signaling. Nat. Genet. 41, 885-890. doi: 10.1038/ng.406

Wang, L., McDonnell, S. K., Slusser, J. P., Hebbring, S. J., Cunningham, J. M., Jacobsen, S. J., et al. (2007). Two common chromosome 8q24 variants are associated with increased risk for prostate cancer. Cancer Res. 67, 2944-2950. doi: 10.1158/0008-5472.CAN-06-3186

Wang, Y., Ray, A. M., Johnson, E. K., Zuhlke, K. A., Cooney, K. A., and Lange, E. M. (2011). Evidence for an association between prostate cancer and chromosome $8 \mathrm{q} 24$ and $10 \mathrm{q} 11$ genetic variants in African American men: the Flint Men's Health Study. Prostate 71, 225-231. doi: 10.1002/pros. 21234

Wokolorczyk, D., Gliniewicz, B., Sikorski, A., Zlowocka, E., Masojc, B., Debniak, T., et al. (2008). A range of cancers is associated with the rs6983267 marker on chromosome 8. Cancer Res. 68, 9982-9986. doi: 10.1158/0008-5472.CAN-08-1838

Wokołorczyk, D., Gliniewicz, B., Stojewski, M., Sikorski, A., Złowocka, E., Debniak, T., et al. (2010). The rs1447295 and DG8S737 markers on chromosome 8q24 and cancer risk in the Polish population. Eur. J. Cancer Prev. 19, 167-171. doi: 10.1097/CEJ.0b013e32832945c3 
Wong, N., Gu, Y., Kapoor, A., Lin, X., Ojo, D., Wei, F., et al. (2017). Upregulation of FAM84B during prostate cancer progression. Oncotarget 8, 19218-19235. doi: 10.18632/oncotarget.15168

Xu, J., Kibel, A. S., Hu, J. J., Turner, A. R., Pruett, K., Zheng, S. L., et al. (2009). Prostate cancer risk associated loci in African Americans. Cancer Epidemiol. Biomarkers Prev. 18, 2145-2149. doi: 10.1158/1055-9965.EPI-09-0091

Yeager, M., Chatterjee, N., Ciampa, J., Jacobs, K. B., Gonzalez-Bosquet, J., Hayes, R. B., et al. (2009). Identification of a new prostate cancer susceptibility locus on chromosome 8q24. Nat. Genet. 41, 1055-1057. doi: 10.1038/ng.444

Yeager, M., Orr, N., Hayes, R. B., Jacobs, K. B., Kraft, P., Wacholder, S., et al. (2007). Genome-wide association study of prostate cancer identifies a second risk locus at 8q24. Nat. Genet. 39, 645-649. doi: 10.1038/ng2022

Zeegers, M. P., Khan, H. S., Schouten, L. J., van Dijk, B. A., Goldbohm, R. A., Schalken, J., et al. (2011). Genetic marker polymorphisms on chromosome $8 \mathrm{q} 24$ and prostate cancer in the Dutch population: DG8S737 may not be the causative variant. Eur. J. Hum. Genet. 19, 118-120. doi: 10.1038/ejhg.2010.133

Zhang, L. L., Sun, L., Zhu, X. Q., Xu, Y., Yang, K., Yang, F., et al. (2014). rs10505474 and rs7837328 at 8q24 cumulatively confer risk of prostate cancer in Northern Han Chinese. Asian Pac. J. Cancer Prev. 15, 3129-3132. doi: 10.7314/APJCP.2014.15.7.3129

Zhang, X., Chen, Q., He, C., Mao, W., Zhang, L., Xu, X., et al. (2012). Polymorphisms on $8 \mathrm{q} 24$ are associated with lung cancer risk and survival in Han Chinese. PLoS ONE 7:e41930. doi: 10.1371/journal.pone.0041930
Zheng, S. L., Hsing, A. W., Sun, J., Chu, L. W., Yu, K., Li, G., et al. (2010). Association of 17 prostate cancer susceptibility loci with prostate cancer risk in Chinese men. Prostate 70, 425-432. doi: 10.1002/pros. 21076

Zheng, S. L., Sun, J., Cheng, Y., Li, G., Hsu, F. C., Zhu, Y., et al. (2007). Association between two unlinked loci at $8 \mathrm{q} 24$ and prostate cancer risk among European Americans. J. Natl. Cancer Inst. 99, 1525-1533. doi: 10.1093/jnci/ $\operatorname{djm} 169$

Zheng, S. L., Sun, J., Wiklund, F., Smith, S., Stattin, P., Li, G., et al. (2008). Cumulative association of five genetic variants with prostate cancer. N. Engl. J. Med. 358, 910-919. doi: 10.1056/NEJMoa075819

Conflict of Interest Statement: The authors declare that the research was conducted in the absence of any commercial or financial relationships that could be construed as a potential conflict of interest.

Copyright (c) 2018 Tong, Yu, Li, Zhao, Ying, Qu and Mu. This is an open-access article distributed under the terms of the Creative Commons Attribution License (CC $B Y)$. The use, distribution or reproduction in other forums is permitted, provided the original author(s) and the copyright owner(s) are credited and that the original publication in this journal is cited, in accordance with accepted academic practice. No use, distribution or reproduction is permitted which does not comply with these terms. 